\title{
THE FRENCH WORKING CLASS AND THE BLUM GOVERNMENT (1936-37)
}

To the French Left in May 1936, the electoral triumph of the Front Populaire - a coalition of the Communist, Socialist, and Radical Parties - signified nothing if not the victory of legal republicanism over the criminal machinations of domestic fascism. Consequently, embarrassment - not to mention confusion - was widespread, when the proletariat chose to greet this victory with a wave of sit-down strikes that was at once massive, spontaneous, joyful, and utterly illegal. It is true that the roots of the strikers' grievances went much further back than the political campaign of recent months. Five years of lowered wages, poorer working conditions, and the indifference of many employers to the lot of their men ${ }^{1}$ were behind the workers' monumental audacity. Nevertheless, the coincidence of the strikes with Leon Blum's accession to office was far from accidental.

In part, the Left's sweeping victory at the polls meant to the workers that striking was no longer to involve the chance of police repression and mass dismissals. ${ }^{2}$ This feeling of assurance was certainly an important reason for the walkouts. But possibly more important was that, for the proletariat, this new government, soon to take office, had become a beacon of hope. Since the First World War, the French

\footnotetext{
1 Speaking of employer attitudes in the years preceding the Blum regime, Henry Ehrmann, Organized Business in France (Princeton, I957), p. I 2 says: "Absorbed by a constant fight for a share in an always limited and now still-narrowing market, beset by credit difficulties, cynical about domestic policies, many employers knew nothing about the living conditions and the mentality of their own workers." In the same work, on p. 6, Ehrmann refers to the "shocked" and "ashamed" reaction of the employers' representatives at the Matignon Conference in June ' 36 , when CGT leaders presented statistics showing the low wage rates in many industries. See also Henri Prouteau, Les Occupations des usines en Italie et en France (Paris, 1937), p. I04.

2 Cf. Simone Weil, La Condition Ouvrière (Paris, I951), p. I68. The traditional treatment meted to strikers once calm was restored has been described in fictional form in the first part of La Grande Lutte (Paris, 1937), by Tristan Remy.
} 
working class had seen one continental democracy after another destroyed by fascism and reaction. In Italy, Germany, and Austria, it had witnessed the defeat and dissolution of free labor parties and trade union organizations that had been the pride of pre-war social democracy. After February 6, 1934, there was reason to fear that France herself was next. Only a few days before Austrian Socialism was crushed in armed struggle with Dollfuss' police, right-wing rioters at the Place de la Concorde were threatening to lynch the members of the National Assembly.

Indeed, during the years preceding the victory of the Popular Front, right-wing leagues, notably the Croix de feu, had made countless demonstrations and threats against the republican order. No one at the time was sure how much of their display was smoke and how much, fire. But the excellent showing of the left parties in the 1936 elections gave hope that at last a stand, or, better, a counteroffensive might be made against the encroachments of fascism. If some workers were wary of doing anything to antagonize external fascism, because of the war danger, there was no such inhibition regarding the domestic brand. A great feeling of elation filled the partisans of the Front Populaire, and this elation, accompanied as it was by a steep decline in the morale and popularity of the supporters of the Right, encouraged the workers to take a step which without the general exuberance would have been very unlikely. ${ }^{1}$

To be sure, the strikes do not show the workers to have had any child-like faith in the omnipotence of the new regime. They certainly did not see it, as some of their more rabid antagonists did, as a government of Red Revolution. The very fact of locking themselves in and their employers out of the struck plants, while it signified a belief that Blum would not use the Gardes mobiles against them, also showed little confidence in the government's ability to keep their employers from running the plants with strikebreakers. And such a lack of confidence would have been most inappropriate under a truly Bolshevik regime. Indeed, several chronicles of the period present the strikers as feeling the need to "push" Blum into doing something for the workers." But at least Blum was seen as capable of being "pushed" in the right direction, as distinct from the usual chief of state, who when pushed would merely push back with all the armed force at his disposal. Thus, there can be little doubt that despite these reservations, and apart

${ }^{1}$ Cf. Salomon Schwarz, "Les Occupations d'usines en France de Mai et Juin, I936", in: International Review for Social History, Vol. II (1937), p. 5 I.

2 Alexander Werth, Destiny of France (London, 1937), p. 304. A fictionalized account of the 1936 strike, Les Belles Journées by Maurice Lime (Paris, 1949), p. 128, also makes this point. 
from all other factors producing the strike wave, the strikes indicated the workers' enthusiastic support of the new Popular Front government. In return for their support, the workers expected a strong stand against fascism and a major improvement in their conditions of labor.

Little more than a year later, this government, under heavy pressure from the banks and the Senate, was forced out of office. By then the attitude of the workers to the Blum regime had changed drastically. I have seen no better indication of this change than the following statement by a conservative opponent of the Popular Front:

"It had been commonly admitted that the fall of the cabinet would have as an immediate consequence a general strike of the Parisian working class, indeed, large-scale riots. Some spoke of revolution. Now it is a fact that never has a ministerial fall left the street, the public square, so indifferent. Not a movement, not even a cry. No armed force employed. None of our fellow citizens, even among the most confident, could have hoped for such an easy, regular defeat of the cabinet."1

The purpose of this study will be to show how and why this monumental indifference developed out of the workers' initial enthusiasm.

It is traditional to assign to the Communists a role that is not merely Machiavellian but all-powerful in turning the working class against the Popular Front. Noting the strange mixture of ultra-patriotic and left-extremist demagogy in the Communist propaganda output for 1936-37, some of the most acute observers have considered that the Party aimed both at forming right-wing alliances and at turning the working class against Blum, the former, to serve Stalin's policy of the moment, the latter, to prepare a base for an ultimate conquest of power. ${ }^{2}$ The conclusion is then reached that while they failed in the attempt to gain right-wing allies, they were most successful in turning the workers against the Blum regime. ${ }^{3}$ Nevertheless, though there is no question of the duplicity of the Communists, I do not believe that the workers' growing disillusionment with the Popular Front was so much a result as a cause of the confusing maneuvers of the French Communists in $1936-37$.

\footnotetext{
1 Bernard Lavergne, "L’Expérience Blum”, in: L'Année politique française et étrangère, June 1937 , p. I91.

${ }^{2}$ Franz Borkenau, European Communism (New York, 1953), pp. 158, 198; André Delmas, A gauche de la barricade (Paris, 1950), pp. I 16-1 30, passim.

Borkenau, p. 198; Delmas, idem.
} 
The basic aim of Stalin's European policy in the period following the Laval-Stalin pact and continuing at least until the fall of 1937 was to prevent the rapprochement, in a massive European combination directed against Russia, of France and Italy on the one hand and Germany and England on the other. ${ }^{1}$ There is little doubt that fear of this combination, coupled with fear of the already existing BerlinTokyo axis, was communicated to the French party in no uncertain terms, and that its whole energy was directed to winning the sympathy of the French people and government for Russia and against Germany. ${ }^{2} \mathrm{Up}$ to the autumn of 1936 , this tactic is most unequivocal. The Communists showed themselves as super-patriots to the electorate in the election campaign of April, 1936. ${ }^{3}$ They in no way sought the strike wave of May-June 1936 , and, though they capitalized on it very well, for reasons I shall explain shortly, they did everything they could to convince the strikers to go back to work at the earliest possible moment. ${ }^{4}$ When the Spanish Civil War broke out towards the end of July, they consistently played down the revolutionary character of that war, and stressed the need for a "French Front" of all Frenchmen, to save the republican cause and keep France from fascist encirclement. ${ }^{5}$ Their entire appeal was directed not to the working class - though at massive outdoor rallies in August 1936 they gathered great numbers of people, of whom a large proportion were probably workers - but to the parties and adherents of the Right and Center. ${ }^{6}$

For reasons which are inexplicable in terms of the demands of Russian foreign policy, however, this line of action seemed to stop

${ }^{1}$ Max Beloff, The Foreign Policy of Soviet Russia (London, 1946), Vol. I, I929-1936, pp. 90-91. Also cf. Maurice Ceyrat, La trahison permanente, parti communiste et politique russe (Paris, 1947), pp. 40-44, and Borkenau, op. cit., p. 167.

${ }^{2}$ Both Borkenau and Ceyrat hold that the achievement of this friction was the major reason for the communists' attempt to push France into the Spanish Civil War.

${ }^{3}$ Cf. Alexander Werth, The Twilight of France (New York, I942), pp. 77-78.

4 On June 10, 1936, Maurice Thorez somewhat threateningly declared in L'Humanité that it was necessary to know how to end a strike once the essential demands were satisfied. In the July 25, I936 number of Cahiers du Communisme Jacques Duclos told the proletariat that the workers could make their demands triumph not only without recourse to sit-down strikes, but even without striking, since before stopping work, the workers could use other means of pressure on the employers.

5 The "French Front" line was gradually brought out in L'Humanite between July 24th and August ${ }_{3}$ rd, 1936.

${ }^{8}$ In two huge meetings alone, reported in L'Humanité for August xo and 31, 1936, 700,000 people were gathered. Social issues were de-emphasized, national ones stressed, at these gatherings. Joan of Arc and the composer of the Marseillaise replaced Marx and Lenin as Communist saints; the supporters of Franco were compared to the aristocratic intriguers against the French Revolution; and Charles $V$ was adduced to show the menace to France of a Spanish-German coalition. 
rather abruptly in September 1936. The "French Front" slogan was dropped and two large-scale protest strikes against Blum's nonintervention policy signified the beginning of an attack on the Blum regime from the Left. ${ }^{1}$ The most plausible interpretation of this shift is that the working class had maintained considerable autonomy vis-a-vis its environment, including that part of its environment which embodied the propaganda and charisma of the Communist Party. A few brief reflections on the role of the Communist Party in the June strikes and its later relations to the proletariat makes this clear.

In May and June 1936, the Communists came to control the greater part of the rejuvenated labor movement not by attracting the workers to its slogans, but by falling in line with the slogans of the workers. In a sense, the Party was made a prisoner of its working-class base. For years, it had had as the substance of its organization factory cells, which were practically identical with the quasi-legal Communist union locals (CGTU). Because of the strictly centralized hierarchical and conspiratorial nature of these cells, they managed to persist in many areas where CGT locals, with their looser structure and more open operations, were quickly disrupted and dissolved by the dismissals of their members. ${ }^{2}$ Thus the CGTU militants, through the very fact of their continued existence and agitation, and though their numbers were very small, were often held in high, almost mystical esteem by their co-workers. ${ }^{3}$

But this regard was based on the identification of the workers' hopes, however vague and inarticulate they were, with the actions of the local Communist militants. ${ }^{4}$ The distant and obscure international aims of the Party had practically no influence on the mass of semi-and unskilled workers in the factories colonized by the Communists. It

\footnotetext{
1 On Sept. 3, 1936, Thorez, in a speech before I5,000 Renault workers, commended a proposed protest strike against the blockade (L'Humanité, Sept. 4, 1936). On Sept. 7, the metal workers of Paris struck for one hour to protest, among other things, Blum's Spanish policy. These were the first protest strikes on Spain to be sanctioned by the Communist leadership.

2 Michel Collinet, "Masses et militants: la bureaucratie et la crise actuelle du syndicalisme ouvrier français", in: Revue d'histoire économique et sociale, Vol. 29, 195 I, pp. 65-73. Delmas, op. cit., p. 104, offers further reason for Communist control over the union in the ability of the Communists to send their men into the new unions and, because of the workers' lack of sophistication, to get these militants appointed to key positions.

' Collinet, op. cit, loc. cit.

4 This point is made very clearly in M. Lime, Les belles journées (Paris, I 949), pp. $128 \mathrm{ff}$. which is described by the labor historian Eduard Dolléans as "une image romancée, mais exacte de la réalité" (Histoire du mouvement ouvrier, Paris, I953, Vol. III, p. I53). Lime shows how, when the local communist leader fails to back a strike that has begun spontaneously, he is simply ignored until, contravening the orders of his superiors, he agrees to join the strike committee.
} 
was the local and class issues, of significance primarily to the factory in which they worked or, at best, to the class with which they identified themselves - pay rates, hours, conditions of work, etc. - that appealed to the workers and could be used by the Communists in appealing to them. So that when a conflict arose between the macrocosmic demands of Party policy, and the microcosm of a factory or class situation, the local militants, despite instructions from above to prevail in the name of the Party, had either to go along with the class demands of the microcosm or see themselves bypassed.

In May and June, the local militants agreed to take over the leadership of the stay-in strikes despite the discrepancy between the illegal nature of the strikes and the law-and-order pose of the Communist leadership at the time, because if they did not, their own personal influence and that of the Party (it must have been extremely difficult to separate the two) would be dissipated. ${ }^{1}$ After the Matignon Agreement, the Party leaders lost no time in exhorting the proletariat to return to work, and in resuming their pose as defenders of the Republic. ${ }^{2}$

Their tactic was again interrupted, however, and this time permanently, by the renewal of labor unrest in the fall of 1936 . Through the month of August, the workers had shown little more than contempt for the French Front, and the Socialists took no little pleasure in flaying the Communists for their total abandonment of even the theory of class struggle. ${ }^{3}$ These annoyances could be endured, but only as long as there was no reason to fear the wholesale defection of the Party's new working class supporters. And such a defection could come about through a new strike wave, in which the Communists, trapped in their new principles of class collaboration, would be completely bypassed. When in late August and early September, this new series of strikes began in the north of France, where, as Thorez well knew, the Socialists were more powerful than the Communists, the Communist leadership was forced to choose between the

1 Delmas, op. cit., p. 93, says that during the June strikes, "in the conversation of one militant to another", the Communists admitted "that the workers' demands mocked all their slogans, and declared that the wisest thing was to let themselves be carried by the popular current in order to give the impression that they were leading it".

2 See p. 366 , note 4 .

${ }^{3}$ In Le Populaire for August 9, 1936, see Emile Farinet's column, "The Spanish War is a Class War". On August I4, Marceau Pivert condemned the French Front in the Socialist paper, and also stressed the class struggle in the Spanish War. In the August 3 Ist Populaire, Louis L'Hévéder sarcastically rebuffed 'Thorez' repeated pleas for a government "from Reynaud to Marcel Cachin". As for the proletariat, Delmas says that "in the workers' meeting the speeches in favor of the French Front only encountered skeptical smiles and jeers". Op. cit., p. I 24 . 
implementation of its long-range policies and its working-class hegemony. ${ }^{1}$ Since the organizational basis of the party was more than ever in the factory cells, the decision was virtually forced on the top leadership of the Party to call off the French Front slogan, and lend its support to the strikers. ${ }^{2}$

But this tactical maneuver to hold together their working-class organization by no means meant that the Communists had abandoned completely the goal of a new Union Sacrée. If, in the ensuing months, Communists were to belabor the government for its Spanish policy with increasing vigor, it was because this was the only issue open to them which both remained congruent with their basic policy of keeping France at odds with Germany and Italy, and could be used to distract the working class from economic conflicts, thus holding alive the possibility of a future Union Sacrée. In December 1936, the Communists disclosed the intensity of their opposition to non-intervention by making it the only issue in Blum's year of office on which they abstained from supporting him in the Chambre. ${ }^{3}$

But there can be no doubt that if the Communists had their reasons for pushing Blum on the Spanish issue, so had the workers theirs, and the latter were by no means identical with the former. The Communists' continual denial of the revolutionary character of the war in Spain did not hide this character from the average French worker, who felt keen bonds of sympathy for the Spanish workers' militias, and was often enough aware that Russian aid to the Loyalists had been slow in coming and meager when compared to the oratory of the French Communist Party.

An interesting example of this awareness - and one which sheds additional light on the conditional nature of the Communists' control over the workers - emerges from the record of the February 1937 Congress of the "Union of Unions of the Paris Region", the most important regional labor organization under Communist control in France. ${ }^{4}$ In the course of an attempt by a small group of revolutionary

\footnotetext{
1 In an article apparently written in mid-September, Thorez said, "Let us emphasize the fact that strikes are beginning in a district like the Nord, where the Socialists have remained stronger than we". This very interesting article, which strongly suggests the mental anguish of the Communist bureaucracy at being torn away from its "moderate" pose by the resurgence of class conflict, appeared as "The People's Front and Tasks Facing the Communist Party of France", in Communist International, 1936, pp. I45-7 I.

${ }^{2}$ On September 12,1936 , in the name of working-class unity, the Communists renounced the French Front slogan in L'Humanité.

3 Journal Officiel, December 5, 1936, pp. 3377-3378.

- The congress was given extensive coverage in Le Peuple for February 7, 1937, and La Révolution Prolétarienne, February 10, 1937. In my narrative, I have combined these accounts.
} 
syndicalists to have deleted from the organization's official report an endorsement of the Moscow trials and the Stalin Constitution of $1936,{ }^{1}$ Communist hecklers from the audience told the speaker to "go to Mexico", which had just granted asylum to Leon Trotzky. In reply, the speaker pointed out that Mexico had aided Spain before the USSR. Efforts of the Communist leadership to keep control of this meeting extended to cutting off the power supply for a microphone being used by an oppositionist delegate. We may gauge the power which the Communists wielded in this organization, which was thought even by a high CGT official to be totally under Communist control, by the fact that the leadership, fearing to put its line on the trials to a vote, voluntarily withdrew the praise of Stalin's terror and his bogus constitution from their report. ${ }^{2}$

The workers' growing indifference to the Blum regime can thus be understood in its own terms, apart from the maneuvers of the Communists. It developed from three major disappointments, all of which were, with more or less justification, laid at the door of the government: non-intervention in Spain, which they felt to be a betrayal of the government's anti-fascist pledges; the refusal of their employers to recognize their newly-won rights and privileges; and, finally, the material dissipation of the wage gains of Matignon by steep price increases.

It is certain that the desire to lend material support to the Spanish Republic, far from being a mere Communist maneuver, was an instinctive reaction of almost the entire French Left. Everyone regarded the Frente Popular a sister-grouping to the Front Populaire, and the two coalitions were elected to office within ten weeks of each other. When Spanish generals attempted a coup d'etat in July 1936,

1 According to the Bulletin of the International Federation of Trade Unions for February I 7,1937 , the phrases in question were, "the vanguard of Fascism has been revealed and destroyed in Moscow", and "the workers and peasants of Russia, who form one bloc with their government, have recently given themselves the most democratic constitution in the world, which allows of the Trade Unions fulfilling their most useful task".

${ }^{2}$ Le Peuple, February 7, 1937 and La Révolution Prolétarienne, February IO, I937, article by Simone Weil. The CGT official was André Delmas in his A gauche de la barricade, p. 127 . The ostensible reason given by the CP, according to Le Peuple and Weil, was the preservation of unanimity. But surely the Communist leadership must have been aware of the presence of non- and anti-communist syndicalists among the 800 delegates, who were not going to vote for the report as presented. At any rate, the fact that the Communists only withdrew the passages after a fairly influential bloc of old syndicalists came out against them, shows rather clearly that more than a fear for mere unanimity impelled the leadership. 
they carried most of the army with them, and the sole defenders of the republic and the Frente Popular were poorly trained bands of Anarchist, Socialist, and trade-union militiamen. ${ }^{1}$ It was only through the resistance of these units that the coup was turned into a civil war and the republic was given the time in which to build up a new regular army. In the week after the insurgent attack, the Socialist Le Populaire reported many resolutions of support for the Spanish workers from union locals, Socialist sections and Popular Front committees. On July 28 , the miners' union, controlled by non-Communists, ${ }^{2}$ sent a message of solidarity to the Spanish miners. On July 30, the interunion committee of the Paris printers, among whom non-Communists also predominated, ${ }^{3}$ voted a resolution containing the following statement:

"Considering, furthermore, that only popular pressure will put an end to the blackmail of the French fascists and permit to be given to the Spanish proletariat the moral aid and material supplies which it needs for its victory; the interunion committee of the Parisian printers resolves that our reunified CGT should take the initiative as soon as possible for a vast demonstration in favor of Republican Spain."”4

The day before the printers' resolution was issued, the highest leadership of the non-communist workers, in the International Federation of Trade Unions and the Socialist International, mirrored and furthered the sentiments of the rank-and-file with an appeal to "The International Proletariat" that said in part:

"Comrades! You have all felt that if the Republic and democracy were conquered in Spain, a fearful blow would be carried to the cause of liberty in the entire world. No sacrifice will be too heavy to defend such a cause. To those who, down there, are giving their blood and their lives, let us give all the material and moral support that we can bring to bear. Everywhere and in all circumstances demonstrate your real solidarity with the Spanish workers. Demand of the democratic states that, in conformity with the constant rules of international law, the regular and legal government of Spain be able to obtain the necessary means for its defense." 5

${ }^{1}$ Cf. Franz Borkenau, The Spanish Cockpit (London, I937), pp. 64 ff.

${ }^{2}$ Delmas, op. cit., p. 105.

Idem.

4 Le Populaire, July $30,1936$.

- Le Populaire, July 29, 1936. 
Indeed, according to one labor historian, it was felt in France at the time that the dispatching of two French divisions at the outset of the war would have quickly brought victory to the Loyalists. ${ }^{1}$

Blum's declaration of non-intervention of August I, 1936, prompted as it was by Britain's refusal to back France in case aid to Spain produced a war with Germany, did not turn off the flow of appeals by Socialists and trade-unionists. ${ }^{2}$ In Le Populaire for August 19, 1936, Jean Longuet's column was headed "Justice for Spain" and concluded: ".... either immediate and complete neutrality or .... the British and French governments ought to grant to the Spanish government the material it needs." And on August 22nd, the Administrative Commission of the CGT, fully controlled by non-Communists, demanded "for the constitutional government of Spain the guarantees of international law, which allow it to supply itself freely for its defense against the rebel generals in the service of fascism". ${ }^{3}$ Perhaps the height of feeling against the government came with the fall of Irun on September 4th, 1936. A small town in the Pyrenees near the French border, Irun could only be supplied by the Spanish government through French territory. The necessary supplies and ammunition were allowed into France, but not out again. As a result, the defenders of Irun, after an heroic struggle that was in the headlines of the French workers' press for days, were forced to give up the town. ${ }^{4}$

Blum, who did his best not to lose touch with the workers' sentiments, ${ }^{5}$ had had ample opportunity before Irun to feel the pressure mounting against his policy. As early as the end of July, a speech of his in memory of Jaurès had been interrupted by cries of "Airplanes for Spain". ${ }^{6}$ Shortly after the fall of Irun, therefore, at Luna-Park near

\footnotetext{
${ }^{1}$ Eduard Dolléans, op. cit., p. 162.

2 There is much opinion that asserts, to the contrary, that, non-intervention was proposed entirely on the initiative of France. However, the account of Pertinax in the Gravediggers of France, p. 433, quoted approvingly in Claude Bowers' My Mission to Spain (New York, 1954), p. $28 \mathrm{I}$, is very explicit and, unless fabricated out of whole cloth, leaves no room for doubt that, though the announcement came from France, England was primarily responsible. Werth, Destiny of France, p. 379 also supports this account.

${ }^{3}$ Le Populaire, August 22, 1936.

4 The French refusal to allow Spanish munitions to cross back into Spain is recounted in Claude Bowers, op. cit., pp. $280-283$.

${ }^{5}$ According to Sturmthal, Blum's contact with the working class was "far more intimate than Ramsay MacDonald or any German Social Democratic minister had ever thought necessary". And Delmas supports this in relating how, at the Matignon Conference, Blum urged Communist union officials: "Don't call me Mr. President; I have done nothing to merit this. Call me Blum, as always". Adolf Sturmthal, Tragedy of European Labour (London, 1944), p. 234; André Delmas, op. cit., p. 94.

${ }^{6}$ Sturmthal, idem.
} 
Paris, Blum made an impassioned plea for the workers to give their support to his policy:

"Do you think I do not share your feelings? .... When I read in the papers about the fall of Irun and the agony of the last militia-men, do you think that my heart was not with them too? .... And do you think me suddenly incapable of reflection and foresight? Do you think I do not understand what it all means? Believe me, if I have acted as I have done, it is because I knew that it was necessary." 1

The necessity, Blum went on, derived from the fact that if France renounced non-intervention, so would Germany and Italy, whose heavy industries could more easily supply arms for the rebels than could those of France for the Loyalists. He added that there was not a single piece of evidence supporting the claim that Hitler and Mussolini were violating the non-intervention Pact; that France, having been the originator of this pact, could hardly tear it up when the ink was still wet on it, ${ }^{2}$ and that, finally, intervention might well lead to war with Germany.

The audience which Blum addressed appeared to be mollified if not won over by his arguments. But whatever the victory won by Blum at Luna-Park, his definitive statement that the government would not, because it could not, aid the republicans of Spain, seriously harmed his future relations with the proletariat. For even among those who were convinced by him, the hope for a determined stand against fascism, which had been placed in the Front Populaire government, must have been severely shaken. Here was a regime which was swept into office on the basis of an essentially negative program - defense against fascism - and whose triumph was interpreted as a turning point in the world struggle between fascism and democracy. To be sure, it had dissolved the Croix de feu and other paramilitary bands. But since the fall of the conservative Doumergue government in late r 934 did not produce the fascist putsch which had been threatened for that occasion, most people came to realize that the threat of French fascism had been overrated. ${ }^{3}$ While the threat of domestic fascism was waning, however, that of the international variety grew. The French Left had suffered the passivity of its government during the Italian

${ }^{1}$ Quoted in ibid., p. 234. With the exception noted below, all the other details of the Luna-Park speech are from this source.

2 Delmas, op. cit., p. I 7 .

${ }^{3}$ Cf. Alexander Werth, Destiny of France, pp. 72-92, 250; and Franz Borkenau, European Communism, p. I 16 . 
conquest of Ethiopia and Hitler's reoccupation of the Rhineland without becoming demoralized because, after all, it was a bourgeois government that had behaved so spinelessly. But when the workers saw their own political leadership behaving in the same manner, and offering good (if not sufficient) reasons besides, the good will that marked Blum's first weeks in office received its first douche of cold water.

Thus, the workers entered the fourth month of Front Populaire government with a bitterness that was soon to be increased by renewed conflict between labor and capital. Though they had probably not yet turned their backs on the Popular Front, they were soberly impressed by its limitations, and impatient of them.

\section{III}

The greatest strike wave France had ever experienced reached its crest in the second week of June, 1936, when over a million men downed their tools. ${ }^{1}$ Thereafter, the major demands of the strikers having been satisfied, strikes slowly subsided. By the third week of July, all but 33,000 people had returned to work, ${ }^{2}$ and on August I 7 th and i 8 th, for the first time since May, Le Temps failed to print a line of strike news. This calm was quickly broken by a new surge of unrest that had little of the peaceful character of the earlier sit-down strikes and seemed to be caused as much by employer intransigence as by a rapidly rising cost of living. ${ }^{3}$

On August igth, one of the first strikes reported after the midAugust hiatus was a strike of government workers. ${ }^{4}$ This was a particularly bad omen for the Blum regime. The Civil Servants' Federation had always been noted for its lack of the endemic incivisme which made so many Frenchmen view their government as an independent predator rather than an embodiment of the public interest. And of all the trade union groups, the civil servants were considered closest to the Socialists. ${ }^{5}$ Indeed, according to André Delmas, the fonctionnaires were "the elements on which [Blum] counted on being able to support himself with most security". "If this

${ }^{1}$ Henry W. Ehrmann, French Labor from Popular Front to Liberation (New York, 1948), p. 4 I.

2 Le Populaire, July 2I, 1936.

${ }^{3}$ Cf. Joel Colton, Compulsory Arbitration in France, 1936-1939, p. 28; Michel Collinet, L'Esprit du Syndicalisme, p. 127; and John C. De Wilde, "The New Deal in France", in: Foreign Policy Reports, Sept. 1, 1937, esp. p. 140.

${ }^{4}$ Le Temps, August 19, 1937.

${ }^{5}$ Eduard Dolléans, Histoire du Mouvement Ouvrier, Vol. III, p. I 44.

- Delmas, op. cit., p. 47. 
was all Blum could expect from his friends, what must his enemies be preparing!

The plans of Blum's enemies in the reorganized employers' federation soon became clear. Through a resolute campaign of resistance to organized labor, the new Confédération Générale du Patronat Français, was determined to prevent any new gains by labor and to take back as many of the concessions granted at Matignon as possible. ${ }^{1}$ One of the most anti-union of the employers' sub-groups, because of the nineteenth century paternalism of most of its members, was the textile employers' federation. ${ }^{2}$ This group was even more eager to recoup the losses of June than the CGPF, which it had left in disgust after Matignon and refused to rejoin. Thus, the strikes of late summer and early fall, 1936, had four principal characteristics. A great many of them took place in textile mills, which were concentrated in the north of France. They were frequently touched off by dismissals of union workers, and the fear of lockouts. They were aggravated, where not actually caused, by sharp rises in the cost of living. ${ }^{3}$ They were usually

${ }^{1}$ At the time C. J. Gignoux, the new head of the employer group, though he stated his belief that the 40 hour week was a "serious error", denied that he desired the revocation of the social reforms granted in June 1936. Cf. his Patrons, soyez patrons (Paris, 1937), pp. 7, 33. But in a work written under the German occupation, Gignoux showed a bitter hostility to certain of the reforms, especially to the 40 hour week, which he now less temperately described as an "insanity”. Cf. G. J. Gignoux, L'Economie française entre les deux guerres, 1919-1939 (Paris, 1942), Pp. 307 ff. Ehrmann says that "the CGPF flatly turned down requests by the government to facilitate the working of the new legislation through a new and more elaborate understanding with labor". H. W. Ehrmann, Organized Business in France (Princeton, 1957), p. 37.

2 Henry W. Ehrmann, in Organized Business in France, discusses the relation of the textile employers to the new CGPF on p. 1 s. An article in the left Radical La Lumière for Sept. I9, 1936, titled "Le Conflit du textile du Nord: Premier vague d'une grande offensive des féodaux de l'industrie", referred to "the desire for combat of the great conservative families: Michelin and Clermont-Ferrand; the cotton manufacturers of the Vosges; the textile masters of Lille ... They want to break the union power and dissolve the Popular Front."

3

TIME SERIES ON WAGES AND PRICES

A verage male hourly wage for 43 "professions" (all cities outside Paris): October, 1935 $3.80 \mathrm{frs}$; October, $1936-4.42$ frs. (percentage increase: $16.3 \%$ ).

Average female hourly wage for 7 "professions" (all cities outside Paris): October, 1935 2.26 frs.; October, $1936-2.62$ frs. (percentage increase: $15.9 \%$ ).

Retail Price Index for 34 Articles, April-Nov. 1936 (July I914 = 100):

Towns of more than Paris 10,000 inhabitants

April

May

June

429

$45 I$

July

459

461

461 
prolonged by the refusal of the employers - especially the textile employers - to negotiate until their workers left company property. ${ }^{1}$

On August 19 th and 2oth, this new pattern began to appear with strikes in the Nord and other departments over dismissals and layoffs of workers. On August 22nd another strike in the Nord, at Lille, developed over the employment of non-union labor: on the 24th, a sympathy strike was declared in nearby Roubaix and Tourcoing. All three of these cities were major textile centers. The festive mood of the June strikes was absent: at least one case occurred where strikers went to the home of a non-striking worker and destroyed property. ${ }^{2}$

On August 25, the Talbot factory locked out I,000 workers in the Paris area, claiming it could not meet the new wage rates. The workers countered that orders were plentiful and that the only reason for the lockout was to exert pressure on the government to obtain credits. More lockouts were feared. On August 29th, I, 100 men occupied a plant in Belfort. On August 3 oth, more strikes, especially in the Nord, over dismissals of union members, were reported. On August 3 ist, 5,000 coal miners of the northern region left their pits.

The pace of the new strike wave accelerated almost daily. On September $3 \mathrm{rd}, 1,800$ weavers sat down in their plants at Amiens, while strikes for higher wages involved $I, 400$ men in Soissons. The $4^{\text {th }}$ saw 6,000 metallurgy workers leave their jobs in Grenoble. The

$\begin{array}{lll}\text { August } & 453 & 477 \\ \text { Sept. } & & 494 \\ \text { Oct. } & & 515 \\ \text { Nov. } & 508 & 534\end{array}$

Cost of living Indexes for Paris and France

(Indexes reflect the expenses for supplying a workers' family of four):

\begin{tabular}{|c|c|}
\hline \multicolumn{2}{|c|}{ France $(1930=100)$} \\
\hline Not $T$ & \\
\hline 193 & \\
\hline Nov. I93 & \\
\hline
\end{tabular}

$\begin{array}{cc}\text { Paris - I936 (1914 }=\text { 100) } \\ \text { Ist Quarter } & 486 \\ \text { 2nd Quarter } & 497 \\ \text { 3rd Quarter } & 504 \\ \text { 4th Quarter } & 540\end{array}$

(Figures reflect quarterly averages)

Source: Statistique générale de la France (quarterly bulletin).

1 On Sept. 23, 1936, Le Temps reported that too textile employers meeting in Tourcoing refused to negotiate with the unions under the menace of force: presumably meaning sit-down strikes. On the same day, the Cotton Syndicate of the East reportedly refused to discuss with the union as long as union pickets forbade entry into the textile plants, which had already been evacuated. On the 28 th of October, 1936 , Le Temps reported that coal dealers in Roubaix-Tourcoing would not talk with strikers until they evacuated the yards and withdrew their pickets.

${ }^{2}$ Le Temps, August 24, 1936. All dates given in this and the next four paragraphs are the date on which the strike report appeared in Le Temps. 
next day, presumably under the pressure of their employers' refusal to negotiate, the weavers of Amiens agreed to leave their plants for the duration of the strike. In the following four days, a rash of strikes by dockers and shipyard workers broke out in La Seyne, Cherbourg, and La Rochelle. On the tenth of September, to,000 metallurgy workers in the Nord struck for wage increases to keep up with the cost of living. On the I Ith, 30,000 textile workers locked themselves into their factories in Lille.

Two days later, the Lille strikers, under government pressure, agreed to evacuate their plants, only to reoccupy them on the i4th after their employers broke off negotiations. On the i 7 th, 24,000 textile workers in the Vosges struck, while the Lille strike continued. After an attempt at government arbitration failed because of the employers' refusal to cooperate with the government, the strike in Lille was settled by a compromise on the igth. On the same day, the Hotchkiss workers in Clichy walked out because of feared dismissals, and returned only when assured they would not take place.

The next day, September 2oth, Le Temps reported major strikes in progress at Douai and Marseilles in metallurgy, and at Amiens, in the Vosges, and at Lyons, in textiles. On the $2 \mathrm{sst}$, textile workers in Roubaix and Tourcoing prepared to strike, while a small textile plant in Lille, employing 70 men, closed down because it could not afford to pay new wage rates. The Roubaix-Tourcoing strike was avoided, but on the 24th, the epidemic of metal workers' walkouts reached Paris, and sent men out by the tens of thousands. The strikes of textile workers in Vosges and Lyons remained unsettled, and, on the 26th of September, a special meeting of the CGT's national committee was called to review the situation.

In his speech before this body, Jouhaux condemned both the provocations of the employers and the inexperience of the workers and ended with an important new list of demands for government intervention to control the situation. He condemned the press reaction to the strikes, asserting that "... every move of the workers is savagely exploited to create an atmosphere of panic from which our adversaries hope to gain profit". ${ }^{1} \mathrm{He}$ admitted the unreasoning impulsiveness of the great mass of newly unionized workers, who wanted "immediately, full satisfaction for all their demands", and denounced "troublemaking elements inside each factory", who used this impulsiveness. His conclusion was that it was necessary to "develop in the masses a sense of discipline", which could only be done "by guaranteeing all the acquired rights". To obtain such a guarantee,

${ }^{1}$ Le Temps, Sept. 26, 1936. For an extended argument on the same theme, see "Une mancuvre contre la CGT" by Robert Bothereau, in the October 30,1936 Vendredi. 
Jouhaux made three demands: I) That factories be closed by the government during strikes so that neither workers nor management could get into them; 2) That a mobile scale be established for workers' wages, to keep pace with the cost of living; 3) That a system of compulsory arbitration be established by the government for handling labor disputes. All three of these points were in marked contradiction to the CGT's traditional stand against government regulation. ${ }^{1}$ But with a friendly government, and an unfriendly management, which as the Lille strike showed, was obviously not amenable to any voluntary procedures, the CGT realized it had more to gain than to lose by its proposals.

Neutralization of struck factories would have virtually ended all need for sit-down strikes by removing their most important cause: the workers' fear that struck factories would be run by strikebreakers. Neutralization, however, was bitterly opposed by all employers, and this position, probably coupled with the French public's traditional mistrust of government authority, prevented the measure from even being proposed under the Blum regime. ${ }^{2}$ The mobile wage scale was proposed by Blum a few days after the CGT conference, as part of the devaluation law, but it was quickly rejected. ${ }^{3}$ This left only conciliation and arbitration as possible means of holding down labor conflicts. Though the Chambre was willing to grant Blum rather broad powers to safeguard purchasing power, including an arbitration system, the Senate rejected these on the grounds that no special powers should be given until future events showed their necessity. Blum was finally able to obtain only the authority to establish compulsory arbitration for wage claims arising out of price increases. ${ }^{4}$

This was obviously insufficient, since many strikes had dismissals of union members as their cause. Summing up a good part of the basis for the strike record of September, I936, La Voix du peuple, monthly CG'T organ, complained of "numerous cases of violation of social legislation and of failure to respect the free exercise of union rights. An offensive has been unleashed by certain employers' circles to take back all or part of the advantages granted the workers". ${ }^{5}$ The CGT then went on to repeat its proposals for a conciliation and arbitration system for all industrial disputes. However, there was little hope that the employers could be brought into a voluntary agreement with labor

1 The reasons for the CGT's reversal of policy are detailed in Colton, op. cit., pp. 36-38.

2 Neutralization was later proposed to the Chambre by Chautemps in January 1938 , but it was not passed. Colton, op. cit., p. 6r.

see pp. 381-382.

4 Idem.

- La Voix du Peuple, October 1936. 
on such a system: "These propositions have not encountered ... a very sympathetic response in employers' circles ... The CGPF has recently placed at its head new men whose presence at this post, if one can judge by what one knows of them, does not appear likely to facilitate things."

This proved to be an accurate forecast of what was to happen to Blum's efforts to obtain agreement from the employers on a voluntary system. Negotiations between CGT, CGPF and government representatives started in mid-September and dragged on for ten weeks until, in late November, the employers' delegation walked out for good and Blum was forced to apply to the Assembly for a comprehensive compulsory arbitration bill. ${ }^{1}$

During these months, strike activity, though generally less than a tenth what it had been in June, continued at a very high level. In the last third of 1936 , more strikes $(2,428)$ occurred than in any previous year of French history, while the number of strikers $(295,000)$ exceeded that of any year since $1930 .{ }^{2}$ Prices rose unceasingly, and with them, the cost of living. The actual increase in weekly wages resulting from the June strikes had been about 17 per cent. ${ }^{3}$ But the September retail price indices revealed a six per cent increase in the cost of living over May, the November ones, a I 3.5 per cent increase. ${ }^{4}$ Speaking of the strikes in this period, Joel Colton states, "Had there been no other contributory causes, the rise in prices alone would have been sufficient cause for labor unrest". ${ }^{5}$ It may well have occurred to the workers that what the Popular Front regime had given them in human dignity and a higher standard of living, union-busting employers and rising prices were taking away. In the case of Spain, they had seen that, though Blum's heart may have been in the right place, his foreign policy was anchored in the Thames, and that consequently he could do no more for their unfortunate Spanish brothers than English Toryism would allow him - which was nothing at all. The failure of their government to defend the gains of June was even more galling, since these were, after all, their rights and their wages that were being slowly eroded. The pressure was clearly on Blum to rectify the situation. Not only was he losing vital political support, but his

See pp. $381-383$.

See tables in Colton, op. cit., pp. 13-14.

"M. Kalecki, "The Lesson of the Blum Experiment", in: Economic Journal, March, 1938 , p. 26. Kalecki believes the official figures of $13 \%$ for Paris and $16 \%$ for the rest of France were too low, since they failed "to account sufficiently for the big augmentation of wages in many enterprises where trade union rates were not observed during the depression".

4 See table in Coulton, op. cit., p. 31 .

- Ibid., p. 33. Also cf. Michel Collinet, op. cit., p. I 26. 
whole social and economic policy, built as it was around the idea of inducing economic recovery through increased purchasing power, was in jeopardy. But all Blum could do for the workers was to push compulsory arbitration through the Senate and, as we shall see, this was far from enough.

\section{IV}

The creaky mechanism of the arbitration law that was passed on the last day of 1936 , can best be understood in its actual functioning. As an example of this functioning, arbitration in the Paris metal industry reveals the experience of a large and significant group of workers.

The Paris metallurgical union had grown from a membership of about 10,000 before the strike to 200,000 afterward. ${ }^{1}$ The old CGT militants were overwhelmed by swarms of impatient new recruits who, for the reasons outlined above, were almost all Communist sympathizers. ${ }^{2}$ For years prior to the strike of May-June, I936, the metal workers' union had attempted to enter negotiations with the industry's employers' association. All those attempts had failed because of the employers' refusal to even discuss with the union. Relations between workers and management showed no improvement in the post-strike period. Throughout the latter months of 1936 , their employers made numerous, though largely unsuccessful, attempts to secure a delay in the date for enacting the forty-hour week, attempts which were probably known and resented by the workers. ${ }^{3}$ At the same time, the price rise in the Paris area was nullifying their gains of the summer. As a result of the price rise, the long tradition of antiunionism on the employers' part and the recent September metal strikes, relations between management and workers were a mixture of resentment and mistrust. ${ }^{4}$ In November, 1936, the metal workers reacted vigorously to the destruction of their newly acquired purchasing power by demanding a fifteen per-cent wage increase. ${ }^{5}$ When

\footnotetext{
1 Collinet, op. cit., p. $\times 23$. Colton, op. cit., p. $8 \mathrm{I}$ gives the membership as 350,000 in 1937 .

${ }^{2}$ Collinet says that $90 \%$ of the 200,000 voted the Communist theses. Ibid., p. 123 .

${ }^{3}$ These attempts were discussed in the Rapport annuel de L'union des industries metallurgiques et minières, presented at the General Assembly on February 18, 1937. A 3,000 word excerpt was printed in La Voix du Peuple, March 1937, pp. I76-1 79.

4 On June Io, 1936, Simone Weil had described the working conditions in a metallurgy factory, where she was then taking part in a strike, under the headings of hunger, poverty, fatigue, fear, and coercion. "La Vie et la grève des ouvrières métalles", reprinted in La Condition Ouvrière (Paris, 1951), pp. I62-174. Originally appeared in La Révolution Prolétarienne, June 10, 1936 , under the name S. Gaulois.

5 I am indebted to Joel Colton, op. cit., pp. $8 \mathrm{I}-86$, for all my information on arbitration in the metal industry.
} 
it was refused, the union threatened a strike, but, realizing that compulsory arbitration would soon be passed refrained from any more than token stoppages.

In early January the metal union submitted its demands to arbitration. The man appointed by the government to reach a decision was Professor William Oualid, a scholar known for his labor sympathies. On February 7th, 1937, Professor Oualid handed down his decision. While granting the union's claim that there had been a fifteen per cent increase in the cost of living between May and December, I936, he allowed a wage increase of only 8.5 per cent, less than three-fifths of the price rise. In doing so, he pointed out that granting full compensation for the higher prices would only encourage further price inflation, and so produce more harm for the national economy than good for the workers.

The union protested vehemently against this decision, particularly since there had been a further rise in the cost of living of five per cent between its original demand and the arbitration decision. As a result of its agitation, another arbitration award was granted the metal workers in March, 1937, which brought the total increase over May in weekly wages to between I 2.5 per cent for the highest and I 5.2 per cent for the lowest paid category of workers. But by March the cost of living had risen 20.2 per cent over May, leaving the Paris unionists, after ten months of Front Populaire government, with barely two-thirds of the increased purchasing power they had won for themselves in June.

A sense of mistrust in their employers' good faith had already been instilled in the workers by the persistent attempts of the Union of Metal Industries to obtain a legal delay in the application of the fortyhour week. Now the government proved a disappointment - small wonder that the workers were no longer willing to support it with militant action. Far from being an especially bad case, the experience of the Paris metal union was probably better than average. Indeed, Joel Colton maintains that "it exploited the arbitration system to the maximum and extracted all possible benefits from it ..."1 Summarizing the operation of the 1936 Arbitration Act, Colton says, ${ }^{2}$

“... the arbitrators had tried to hold the line against a runaway wage-price spiral, granting only a partial wage adjustment to cost

\footnotetext{
1 Ibid., p. 81. For other wage adjustments under arbitration in 1937 , see ibid., p. 84. The effects of inflation on the income of less aggressive workers is seen in Collinet's statement that between 1936 (one presumes the beginning of the year) and 1938 , the real wages of civil servants decline by $18 \%$. Collinet, op. cit., p. 126.

${ }^{2}$ Ibid., p. 86.
} 
of living rises, rarely granting complete retroactivity and refusing unanimously to grant automatic sliding wage scales for the future. Their decisions represented a denial, past, present, and future, of total wage compensation for the increased living costs... There is no doubt that the excessive caution of the arbitrators and a consuming concern for preventing inflation resulted in many instances of injustice to labor..." (My emphasis, A.M.)

Colton adds that, from the point of view of the national economy, it could be argued that none of the wage increases were justified, since they encouraged inflation; but this statement in no way vitiates the significance of his assertion that "many instances of injustice to labor" resulted. From the standpoint of the French worker, and from my own standpoint in trying to understand the change in the workers' attitude towards the Blum regime, the crucial fact is that arbitration under a Socialist premier did not grant anything like the full compensation for price increases that the workers expected. ${ }^{1}$

In the Economist for February 13, 1937, a report from France described the public's reaction to rising prices in the following terms:

" 'What is the increase in wages worth if it is absorbed at once by the rise in prices' is the slogan invariably heard in the streets, when a further increase in the price of bread, or wine, or butter occurs. The Popular Front is anxious, and the organs of the Left demand that the rise in prices should be checked at once. The leaders of the Trade Unions are urging their followers to be patient, to 'digest' the labour reforms and to safeguard the victory of the Popular Front. But their patience will not last for long."

The events of the next four weeks were to stretch this patience to the limit and finally to snap it. On the one hand, the government's supporters were urging new reforms which would cost billions of francs; a national unemployment fund; old age pensions for workers; relief for the farmers (whose prices had been fixed before the general price rises); wage increases for civil servants. On the other hand, M. Caillaux had warned that the Senate finance committee would not certify any new expenditures unless accompanied by economies in other areas; the investing public was boycotting government bonds; and Blum seemed ready to try halting the price rises by lowering import duties, which would occasion an inevitable drain on the

1 The Economist of February 20, 1937, commenting on Blum's appeal to the civil servants "for a breathing space, for a respite in expenditure", argues that "a breathing space for wages would be an absurdity if not accompanied by a pause in the rise of prices". 
Exchange Equalization Fund, and so cause the government more financial embarrassment. ${ }^{1}$

In mid-February, 1937 , Blum appealed to the men of the Left for a breathing space. ${ }^{2}$ But in their eyes, practically everything the government had done since the summer was a breathing space. Thus, union leaders partial to the CGT Plan, who had been quiet since the 1936 elections in order to give Blum's social and economic policies a chance to work, now became increasingly vocal $;^{3}$ in doing so, they probably reflected and certainly stimulated the growing disaffection of their troops from the government.

The more radical voice of labor in the weeks from mid-February to early March undid Blum's efforts to gain the confidence of banking and business interests. The consequent precariousness of his financial situation was driving Blum to a complete repudiation of his social and economic policy. But this policy, after Blum had renounced any possibility of aiding republican Spain, and internal fascism had proven to be a paper dragon, was the sole remaining bond between the government and the proletariat. When, on March fifth, Blum finally gave in completely to conservative demands for an orthodox economic policy (by dropping his government's public works program and giving control of the Exchange Stabilization Fund to financial conservatives), he created an irreparable breach between himself and the workers who, for all their suspicions, had hoped for so much from the Socialist premier. The Economist astutely noted this breach when it commented that the great result of the policy change was the shock created in the ranks of the Popular Front, and added that "if the Blum cabinet falls, a successor may come without riots in the street. In that sense", it concluded, "the danger of a revolution is past". 4

Ten days later, in the Parisian workers' suburb of Clichy, street riots did occur. But far from being in defense of the Blum regime, they constituted a bloody proletarian outbreak against it.

\footnotetext{
1 A summary of the CGT's criticism of arbitration as it functioned from its inception to its replacement by a more precise law in May 1938 , is given in the Compte rendu sténographique des débats of the CGT Congrès confédéral de Nantes - I938, pp. 62-63. Immediately following is an analysis of the first two hundred arbitration decisions, as reported in the Journal officiel for September 3, 1937, and February 3, 1938.

2 The Economist, February 20, 1937.

s At the same time that Blum was soliciting support for the "pause", Jouhaux was urging nationalization of banks and industry. Cf. The Economist, February 27, 1937.

4 The Economist, March 13, 1937.
} 
On March 16, 1937, in Clichy, a movie party held by the Parti Social Français, legal descendant of the Croix de feu, provoked an angry counter-demonstration by thousands of workers. According to the account given by Blum to the Cbambre, ${ }^{1}$ local Communist and Socialist leaders made strenuous efforts to have the permit for the meeting revoked by the government, but the government refused. When it became obvious that the mood of the people might bring an attack on the government police guarding the theater, the Socialist mayor, the Communist deputy, the secretary of the Socialist Federation of the Seine, and a Communist general councillor of Clichy all agreed, at a last minute meeting with representatives of the Ministry of the Interior, to lead the counter-demonstration they had jointly organized away from the theater. Some 4,000 workers followed them out of the trouble area, but thousands more remained in an extremely agitated state near the theater, ${ }^{2}$ and some, it was alleged, availed themselves of the opportunity to take pot shots at Blum's police.

Whether provoked by gunfire or not, the police fired on the crowd, and when the smoke cleared, there were five wounded workers on the ground. As soon as the workers in the procession heard the shots, they raced back to the scene of the fighting and the serious bloodshed began. As police reinforcements rolled up by the truckload, the shooting became more frequent. Certainly many of the workers, anticipating a gun battle with the police, had come armed, ${ }^{3}$ and those who had not found no scarcity of stones and pieces of scrap metal to hurl at the gardes mobiles. When Blumel, the Premier's chef $d u$ cabinet, arrived, he was promptly caught in a volley of the gardes mobiles and shot twice. Marx Dormoy, Blum's Minister of the Interior, was a little more adept at keeping out of the line of fire, but when he tried to address the rioting workers, he was drowned out with cries of "Dormoy, démission!" and the fighting went on. ${ }^{4}$ Meanwhile, the police had evacuated the frightened moviegoers through a rear exit,

\footnotetext{
${ }^{x}$ Le Temps, March 25, 1937. Except where indicated, other information in this and the following paragraph is from the same source.

2 The figures are from the account in the Socialist Proletaire de Clichy, reprinted in La Révolution Prolétarienne, April 10, 1937.

${ }^{3}$ The London Times, on March I9, 1937, summed the reason up for this by pointing out that: "In France, every policeman openly carries a loaded automatic pistol, and the gardes Mobiles are equipped with steel helmets, pistols and carbines. When the police, with no weapons but firearms, are hard pressed by the crowd, it is likely that the firearms will go off sooner or later, and when demonstrators know that the police will be armed, they are apt to arm themselves also."

"Le Temps, March 18, 1937.
} 
but when the crowd learned that the object of its initial demonstration was no longer in existence, it only turned with more fury on the gardes mobiles. Workers from neighboring suburbs were only kept from joining the men from Clichy by strategically placed police barricades. ${ }^{1}$ By the time it was all over, there were four dead and probably several hundred wounded workers, and about one hundred and fifty police who had to be treated at the hospitals. ${ }^{2}$ Of some fifty critical cases in the hospitals, most were workers, including one who soon died of his wounds. ${ }^{3}$

The Clichy riots are the clearest indication we have of the more militant workers' attitude after March fifth. In ever greater number they were turning away from the Blum regime, deserting the Front Populaire leadership in the unions and the Left parties, and following left-extremists. ${ }^{4}$ The Clichy outburst was the first and major occasion on which left-extremists successfully contested the authority of the Popular Front over a large group of workers.

Certainly, no other explanation fits the facts of Clichy. Many people at the time believed the Communists were behind the rioting. ${ }^{5}$ But it would have been madness for the Communist leadership to have deliberately provoked the gun battle, for their main goal in French politics was still to seek right-wing allies for a possible union sacrée against Hitler. If the Clichy affair had produced a chain reaction through the rest of the Paris area (as it threatened to do when workers from neighboring suburbs attempted to join their comrades in Clichy), the Communists would have been forced to make an irrevocable choice: either follow the left-extremists into a revolutionary adventure which, besides being almost certain to fail, would be in flagrant contradiction to Stalin's foreign policy; or oppose the left-extremists in the name of unity with the French nation and thereby insure the disintegration of their entire working-class apparatus. Blum, completely exonerating the "responsible" Communist leadership, hinted in his speech to the Chambre that right-wing agents provocateurs fired first. ${ }^{6}$ While this may have been so, it in no way tells us why, in the first

\footnotetext{
1 Idem.

2 The hospitals only received about 80 workers, but in the press, it was generally thought that untold numbers of workers had not reported to the hospitals for fear of punishment. At any rate, the number of wounded police is a good indication that the number of wounded workers was several times eighty.

${ }^{3}$ London Times, March 18 , 1937.

${ }^{4}$ For Alexander Werth's description of left-extremism and an excerpt from the speech of a revolutionary syndicalist at the 1938 Congress of the CGT, see Appendix.

${ }^{5}$ André Delmas, op. cit., p. I 27; Pierre Lazareff, in a chapter on Clichy in Deadline, and Franz Borkenau, European Communism, p. 208.

- Le Temps, March 25, 1937.
} 
place, thousands of workers refused to follow their elected leaders, or why, when the shooting began, the rioters persisted in fighting the police at the peril of their lives.

Obviously, beyond the stated purpose of the demonstration, and responsible for the actual explosion, was the pent-up fury of the more militant workers over the results of Blum's policy: non-intervention, price rises, the wage-sieve of arbitration, subservience to the banks, the pause of February, and the retreat of March 5th. The "fascist provocations", of which the Clichy movie party was a rather paltry specimen, totally out of proportion with the reaction it produced, were no more than "justifiable" opportunities for the workers to vent their spleen against the government indirectly. They could not riot directly against the Blum regime. The premier, for all his betrayals, was a Socialist and a republican: to riot en masse against him would have placed them on the side of their most detested opponents, the rioters of February 6th, 1934, and the monied interests. But to show their hostility by demonstrating first against the fascist provocation at Clichy, then against Blum's police, who protected the fascists, and finally against the Blum regime itself, was within the rules of the workers' political psychology.

On the day following the riot, March $\mathrm{x} 7 \mathrm{th}$, the Paris area was rife with labor unrest. Agitators haranguing the construction workers at the Paris exposition held up work until i I a.m. ${ }^{1}$ The Metro and Autobus unions, apparently without consulting the Paris "Union of Unions", called a twenty-four-hour strike for the 18 th. ${ }^{2}$ Faced with the fait accompli of the transportation strike - which would in any case prevent most of the workers from getting to work in the morning - and with widespread agitation in the workers' suburbs, the "Union of Unions" and the giant metal workers' union, both under Communist control, issued an order for a general strike. ${ }^{3}$ In the very limited scope of the strike, which was to be of only a half day's duration, in the stated aim of the strike, which was to protest only against the resurgence of fascism and not against the government, in the refusal to allow any demonstrations, and in the openly expressed hope that the strike would serve as a safety-valve for the workers' discontent, the strike leaders revealed not only the extreme nervousness and distaste

${ }^{1}$ London Times, March I8, 1937.

2 La Révolution Prolétarienne, April I0, 1937.

${ }^{8}$ Idem. André Delmas, relating the very confused situation on March 18 , implies that the Communists wanted to use the strike as a means of stirring trouble for the Blum regime. But the actual facts he gives correspond to the account in La Révolution Proletarienne, whose conclusion that the Communist-led Union of Unions and Metal Workers Union were forced by rank-and-file agitation and by pressure from the Metro Union to call the strike makes more sense than Delmas' notion of a plot. 
with which they regarded the agitation of the rank-and-file, but also the widening gap that now separated the latter from themselves. ${ }^{1}$

Certainly the strike appeal of the Paris "Union of Unions", printed in Le Temps, was far from an inflammatory document. ${ }^{2}$ It called on the workers "to act with calm and composure, to avoid all provocations, and all street demonstrations, to take up work everywhere in the afternoon in order to demonstrate the power and discipline of our movement". When, on the afternoon of March I 8th, CGT members in several places tried to expel non-strikers from their factories, many CGT delegates opposed the expulsions, sometimes without success. ${ }^{3}$ On the morning of March I 9 th, a communiqué issued jointly by the Paris Union Group and the CGT reminded the workers that the strike had been "limited in objective to the problems raised by the tragic shootings at Clichy", admitted that "at certain meetings orders of the day were voted in favor of different demands", but insisted that "Yesterday's movement should not have as a consequence the continuation of the work stoppage for these demands". ${ }^{4}$ It ended with a virtual order for work to be resumed "everywhere".

The picture I have drawn above - of angry workers ignoring their leaders, of the Communist union leadership forced by pressure from its middle rank leaders and its rank-and-file to act in ways it would prefer not to act, of strikes getting out of the hands even of local union delegates - is mirrored in many statements by centrist and even rightwing spokesmen of the period. Léon Meyer, a deputy of the Radical Socialist Party, said after Clichy: "Even if we should admit the Communist chiefs do not desire to disturb order for the moment, we would be forced to recognize that they no longer have authority over their troops."5 In the Revue des deux mondes, René Pinon says that the CGT chiefs have been pushed aside and forced to obey the dictates of anarchist and Trotzkyist elements. ${ }^{6}$ Pinon shrewdly links the explosion at Clichy to the "riffraff's" anger over the pause. La République, a right wing Radical daily, refers to the "unknown quality of the four million newcomers ... ignorant of union traditions and not yet disciplined".?

\footnotetext{
${ }^{1}$ Michel Collinet astutely argues that the arbitration system was responsible for this gap, first by removing the union leadership from its role as organizer of a real class struggle and transforming it into a simple intermediary between the workers' demands and the government arbitrator; secondly, by putting the leadership in the position of accomplice to the erosion of real wages under arbitration. Esprit du syndicalisme, pp. I 26-I 27.

2 Le Temps, March I9, 1937.

' Ibid., March 21, 1937, and London Times, March 23, 1937. The incidents continued for several days after the strike.

${ }^{4}$ Le Temps, March 20, 1937. 5 Ibid., March 18, 1937.

- Revue des deux mondes, April I, 1937, p. 714.

7 Le Temps, March 20, 1937.
} 
It adds, "the Communists seem no more confident than the CGT'ers before the reaction of this popular mass".

\section{VI}

With the militant workers in such a mood of rebellion against their official leaders, it is no wonder that they could view the demise of the Blum Ministry with equanimity. But when Blum resigned, it was not only a cabinet that fell in France. It was the last hope of binding together a terribly divided nation.

Perhaps that hope was lost in June 1936, when a bold program of nationalizations and exchange control might well have tied the workers firmly to the regime without alienating the bulk of the middle class. But Blum had been caught unawares by the strikes of June and did not know how to use them.

Since the Blum regime failed to make the necessary basic economic reforms, it was impossible to prevent a continual, though losing, struggle on the part of the workers to preserve their gains of the summer. This struggle pushed the workers to the left, while Blum drifted to the right. The workers became progressively more hostile to the government and less receptive to patriotic appeals. While the government shift to the right continued under Chautemps and Daladier, left extremism increasingly gave way to apathy. As the workers, deprived of virtually all their gains by price rises and the revocation of the forty hour week, saw the Popular Front disintegrating, the government turning against them, and the union movement splitting into hostile fractions over the war issue, many of them tore up their union cards in disgust. ${ }^{1}$

The failure of the general strike of November, 1938 , undertaken at a time when union militants were no longer being followed by the rank and file, led to severe reprisals by employers and a mass exodus from the CGT. ${ }^{2}$ By the end of $1938,3,000$ of the CGT's 18,000 local unions had disintegrated. ${ }^{3}$ Nine months later, at the beginning of the war, CGT membership had fallen back from its peak of five million in 1936-37, to what it had been in January 1936- one million. ${ }^{4}$ The great

\footnotetext{
1 Probably the best account of this process is in Ehrmann, op. cit., pp. 77-1 25. Also, see Collinet, Esprit du syndicalisme, pp. 126-127.

?. Ehrmann, op. cit., pp. II $5-120$.

${ }^{3}$ Collinet, op. cit., p. 127.

${ }^{4}$ Collinet, op. cit., p. I 25 . Ehrmann, using an estimate supplied by union officials in the summer of 1939 , says thete were probably still two million CGT members at the outbreak of war. But Collinet was an active trade unionist at the time, and the discrepancy between his and the semi-official figures can probably be attributed to the desire of the officials only to teveal losses which absolutely could not be hidden or denied.
} 
workers' movement that had been spawned by the Popular Front victory in 1936 was broken.

$$
\text { APPENDIX }
$$

\section{ON LEFT EXTREMISM}

I. Alexander Werth, "The Front Populaire in Difficulties", in: Foreign Affairs, July, 1937, pp. 609-618.

Pp. 6I6-6I7: If one were asked who these Left Extremists are, one would be a little baffled how to reply. Such extremism is a state of mind rather than a definite program of this or that organization. There are, of course, definitely extremist elements scattered through the Paris working class - Anarchists, Revolutionary Leninists (popularly known as "Trotzkyists"), the Revolutionary Left of the Socialist Party itself (its leader is Marceau Pivert). But it is difficult to attribute the great importance which left Extremism had recently acquired to anybody in particular. It is an attitude that exists among the rank-andfile of certain trades, e.g., the building trades; it exists in the offices of the CGT, where its proponents are far more extremist than the Communists. One hears a great deal of a Left Opposition in the making and of a Fourth International. All this is so far rather vague, even though the Temps recently drew up a whole catalogue of groups and organizations potentially belonging to the "Left Opposition".

But, as just remarked, this "Opposition" is a state of mind more than anything else - a state of mind that has existed from time immemorial in the Paris working class; that existed among the anarchists and syndicalists before the war; and which is again reflected in the present latent rebellion among certain working class elements against the Blum Government. Like the Anarcho-Syndicalists of pre-war trade unionism, this state of mind is hostile to bourgeois democracy (however progressive) and to normal, regulated relations between labor and capital. Much of this revolutionary temper is spontaneous, as were in June 1936 , the two great strike waves which, at times overwhelmed even the Communist leaders by their revolutionary temper. Trotzky was not altogether wrong when he ridiculed Blum and Jouhaux for describing the great strikes as "professional" and "economic" and for trying to ignore or underrate the underlying revolutionary ferment. As things are today, the tendencies evidenced in June 1936 cannot be ignored, and the Communists and most of the CGT leaders find themselves obliged to play up to the extremists for fear of being denounced as the flunkies of capital - or of Stalin - and so of losing even the nominal leadership of the working class. 
2. Confédération Générale du Travail, Compte rendu sténograpbique des débats, congrès confédéral de Nantes - 1938, p. I64.

[The November 1938 Congress of the CGT at Nantes - the first CGT Congress since January 1936 - was the occasion for much bitter factional strife, as well as protest against the weakness of the parliamentary popular front and the growing strength of the Right. Probably the clearest expression of Left Extremist opinion at Nantes was by a delegate of the Teacher's Union, Serret, who claimed to speak "in the name of the revolutionary minority dispersed in the bosom of the CGT". After citing attempts by the CGT to persuade the workers to evacuate the factories in July 1936, and by the Communist Party to convince them not to strike at all, Serret said:]

It is in this way, by renouncing strike and sit-down strike alike, that they have prepared the Pause, which preceded the capitulation of the union movement before the politicians of the Popular Front.

It could not have been otherwise; the Popular Front, since its formation, had enclosed itself in the framework of the capitalist regime and, in doing this, it condemned itself to a sterile action, to the demoralization of the workers, to the most stinging setback, in order to achieve, in the last analysis, the National Front, the Front of social reaction.

Comrades, the parliamentary Popular Front - which we do not confuse with the Popular Front of combat desired by the workers has done absolutely nothing. Bread is more dear than ever, liberty is strongly contested at the present moment, as far as peace, you know what we have almost had. We have been ... through the will of certain factions of the Popular Front, a few millimeters from war. And if war had broken out, we would have experienced the total crushing of all popular demands, the suppression of all our liberties and - tragic culmination, the extermination of the proletariat. Thanks to the Stalinists, to the CGT, to the Socialists, to the Radical reaction, we have almost had the most atrocious war imaginable, the most formidable dupery conceivable. And this after having promised to the workers: Bread, Liberty, and Peace!

It is therefore necessary to break with this formation of treason that is the Popular Front; it is necessary to denounce it, and to replace its electoral program with a program conforming to the interests of the workers; it is necessary to substitute for dupery and political inaction, the virile action of a CGT inspired with the class struggle. 